\title{
Sağlık Kurumlarında Çalışan Hemşirelerin Tükenmişlik Algılarının İşten Ayrılma Niyetlerine Etkisi (Burnout Perceptions of Nurses Working in Health Institutions Effect on Intentions to Leave)
}

\section{Özlem KÖROĞLU iD a Emel BAHAR (iD b}

a Toros Üniversitesi, Sağlık Bilimleri Fakültesi, Mersin, Türkiye. ozlem.koroglu@toros.edu.tr

b Tarsus Üniversitesi, Meslek Yüksekokulu, Tarsus, Mersin, Türkiye. ebahar@tarsus.edu.tr

\begin{tabular}{|c|c|}
\hline MAKALE BİLGİSİ & ÖZET \\
\hline $\begin{array}{l}\text { Anahtar Kelimeler: } \\
\text { Hemşirelik } \\
\text { Tükenmişlik } \\
\text { İşten Ayrılma Niyeti }\end{array}$ & $\begin{array}{l}\text { Amaç - Sağlık emekçileri içinde en büyük grubu oluşturan ve hasta ile birlikte uzun süreli çalışan } \\
\text { hemşireler, çalışma ortamındaki olumsuzluklardan en fazla etkilenen sağlık çalışanları olarak kabul } \\
\text { edilmektedir. Bu çalışmanın amacı, sağlık kurumlarında çalışan hemşirelerin tükenmişlik algılarının işten } \\
\text { ayrılma niyetlerine etkisini incelemektir. }\end{array}$ \\
\hline
\end{tabular}

Gönderilme Tarihi 18 Ekim 2021

Revizyon Tarihi 8 Aralık 2021

Kabul Tarihi 15 Aralık 2021

Makale Kategorisi: Araştırma Makalesi
Yöntem - Araştırmada, nicel araştırma yöntemi kullanılmıştır. Araştırmanın verileri zincir örnekleme yöntemiyle, Mersin ve Adana illerinde erişilebilen ve çevrimiçi ankete katılım gösteren 464 hemşireden elde edilmiştir. Veri toplama formu Tükenmişlik Ölçeği, İşten Ayrılma Niyeti Ölçeği ve demografik sorulardan oluşmaktadır. Araştırma sonucunda elde edilen verilere SPSS ve AMOS programında regresyon ve korelasyon analizleri yapılmıştır.

Bulgular - Tükenmiş̧liğin alt boyutlarını oluşturan, duygusal tükenme ve duyarsızlaşmanın, bağımlı değişken işten ayrılma niyeti üzerinde anlamlı ve pozitif bir etkiye sahip olduğu; üçüncü boyut olan kişisel başarının, bağımlı değişken işten ayrılma niyeti üzerinde anlamlı ve negatif bir etkiye sahip olduğu görülmüştür. Ayrıca işten ayrılma niyetinde olan hemşirelerin \%38'inin işini bırakmayı son 1 yıl içinde düşünmeye başlamış olmasının, Covid-19 salgını sürecinin yoğun ve yıpratıcı etkisiyle ilgili olması yüksek ihtimaldir.

Tartışma - Önceki çalı̧̧malarda önerilen duygusal emek davranışı geliştirme çabalarının çok ötesinde sistemli ve sürdürülebilir programlarla, ülke genelinde ve tüm sağlık sektörü çalışanlarını içerecek şekilde stratejiler formüle edilmeli ve uygulanmalıdır. Özellikle kişilik özellikleri başta olmak üzere çok farklı değişkenleri dikkate alarak yapılacak kapsamlı ve boylamsal çalışmalar, sağlık çalışanlarının işe alınması, çağın ihtiyacına göre eğitim ve gelişim sağlanması ve elde tutulması konusunda kilit rol oynayacaktır.

\section{ARTICLE INFO}

\section{ABSTRACT}

Keywords:

Nursing

Burnout

Intention to Leave

Received 18 October 2021 Revised 8 December 2021 Accepted 15 December 2021

Article Classification: Research Article
Purpose - Nurses, who form the largest group among health workers and work with the patient for a long time, are considered as the health workers who are most affected by the negativities in the working environment. The aim of this study is to examine the effect of burnout perceptions of nurses working in health institutions on their intention to leave.

Design/methodology/approach - Quantitative research method was used in the study. The data of the study were obtained from 464 nurses who participated in the online survey in Mersin and Adana provinces by chain sampling method. The data collection form consists of the Burnout Scale, the Intention to Leave the Job Scale and demographic questions. Regression and correlation analyzes were performed on the data obtained as a result of the research in SPSS and AMOS programs.

Findings - Emotional exhaustion and depersonalization, which are the sub-dimensions of burnout, have a significant and positive effect on the dependent variable of turnover intention; The third dimension, personal achievement, was found to have a significant and negative effect on the dependent variable of turnover intention. In addition, the fact that $38 \%$ of the nurses who intend to quit their job have started to think about quitting their job within the last 1 year, it is highly likely that this is related to the intense and wearisome effect of the Covid-19 epidemic process.

Discussion - Strategies should be formulated and implemented across the country and in a way that includes all health sector workers, with systematic and sustainable programs far beyond the emotional labor behavior development efforts suggested in previous studies. Comprehensive and longitudinal studies, which will be carried out taking into account many different variables, especially personality traits, will play a key role in hiring health workers, providing and retaining training and development according to the needs of the age. 


\section{Giriş}

İş dünyasında meydana gelen makineleşme ve teknolojik gelişim, çalışma hayatının öznesi konumunda olan insanın yoğunluğunu ve yaşam temposunu da artırmış, giderek fizyolojik ve psikolojik olarak yıpranmasına sebebiyet vermiştir. Özellikle çalışma ortamında hizmet verdikleri kitle ile yüz yüze ve yoğun iletişim gerektiren meslek dallarında daha sık görülen stres, yorgunluk ve yıpranma, sadece bireye değil, hizmet verilen hedef kitleye ve çalışılan örgüte de negatif etkiler yaratmaktadır.

Sosyal iletişimin yoğun yaşandığı iş ortamlarında görülme olasılığı yüksek olan, birden bire ortaya çıkan ani bir sorun olmaktan ziyade, "enerjinin giderek azalması" şeklinde kendisini yavaş yavaş hissettiren; bu öncül belirtilerin dikkate alınmaması, önleme yoluna gidilmemesi halinde meydana gelen durum ise "tükenmişlik sendromu" şeklinde ifade edilmektedir (Baron ve West, 2007:2161; Savran, 2013:4).

Bireylerin yaşamlarının her aşamasında karşılaşılabilecek bir durum olan tükenmişlik sendromu, son yıllarda, çalışma hayatının üzerinde en çok çalışılan konularından biridir. Hizmet sektörü, tükenmişlik sendromuna yoğun şekilde maruz kalınan meslek gruplarını barındıran birincil risk grubunu oluşturmaktadır. Hizmet sektörü içinde de özellikle sağlık kurumlarında çalışanların tükenmişliği yoğun şekilde yaşadıkları yapılan çalışmalarla ortaya konmaktadır (Barutçu ve Serinkan 2008; Metin ve Özer, 2007; Kebapçı ve Akyolcu, 2011; Akpınar ve Taş, 2011; Karadağ vd., 2002; Demir vd., 2003; Kocabıyık ve Çakıc1, 2008; Özbaş vd., 2006; Şahin vd., 2008). Sağlık mesleği grupları içerisinde ise hemşireler, tükenmişlik oranının en yüksek gözlemlendiği grubu oluşturmaktadır (Taycan vd., 2006:106; Simat, 2007:28). Hemşirelerin iş yaşantılarında birçok negatif faktörle karşılaşmaları nedeniyle; bu durumlar onların psikolojilerini, sosyal yaşantılarını ve iş verimliliklerini de negatif etkilemektedir (Duquette vd., 1994:340; Lee vd., 2003:539). Çünkü hemşireler sağlık kurumlarında hasta ve yakınlarının her türlü sorunlarını ilettikleri birinci kademedir ve bu konuda kilit role sahiplerdir. Uzun çalışma saatleri ve yoğun tempo, acı çeken insan grubuyla -hatta ölümcül hastalarla- bir arada olmanın verdiği stres, hasta ve hasta yakınları ile zaman zaman yaşanan çatışmalar hemşireleri tükenmeye, duyarsızlaşmaya ve zamanla meslekten ayrılmaya yöneltmektedir (Tayfun ve Çatır, 2014:348).

Alanyazında, hemşireleri tükenmişliğe iten nedenler incelendiğinde; bireysel, örgütsel ve işle ilgili nedenler şeklinde gruplandırıldığı görülmektedir. Bu gruplandırmaya göre bireysel etmenler; cinsiyet, yaş, sağlık durumu, eğitim, kişilik, stresle mücadele yeteneği örneklendirilebilir. Örgütsel etmenler; iş güvensizliği, bürokrasi, rol belirsizliği, işyerindeki sosyal desteğin azlığı, kararlara katılamama, yöneticilerden destek alamama, takım arkadaşlarıyla yaşanan çatışmalar, uzun çalışma saatleri, katı yönetim politikaları, hastalarla yoğun etkileşim, kariyer beklentilerinin gerçekleşmemesi gibi etmenler sayılabilir. İş ile ilgili etmenler ise; uzun ve vardiyalı çalışma süreleri, zaman baskısı, iş yükü, maaş yetersizliği, mesleğin prestij ve statü algısı yaratmaması, işin çok yönlü olması ve aynı zamanda zihinsel ve fiziksel güçlüğü vb. nedenler hemşirelerde tükenmişliğe neden olabilmektedir (Yavuzyılmaz vd., 2007:44; Poncet vd., 2007:701; Ebrinç vd., 2002:163; Dolunay ve Piyal, 2003:42; Kaçmaz, 2005:70; Embriaco vd., 2007:482; Shımızutanı vd., 2008:328; Dede ve Çınar, 2008:8; Şahin vd., 2008:120). Bütün bu olumsuzlukların yanında, son bir buçuk yıldır yaşanan Covid-19 salgın süreci, tüm sağlık çalışanları gibi hemşirelerin de özel, iş ve sosyal yaşamını derinden etkilediği, tükenmişlik düzeylerini artırdığı gözlemlenmektedir (Arpacıoğlu vd., 2021:96; Yakut vd. 2020:254; Tekin, 2021:43-44). Öte yandan, işyerlerinde yaşanan bu tür sıkıntılı durumlar, çalışma yaşantısının niteliğini zedelemekte, direkt ya da endirekt şekilde iş üretme maliyetlerini artırmakta, mesleki motivasyonu azaltarak çalışanların işlerinden ayrılmalarına sebebiyet vermektedir. Oysa örgütlerin var olması, çalışanlarının örgütte kalmalarına ve örgüte güçlü bağlarla aidiyet hissetmelerine bağlıdır (Silah, 2005:170; Salmela-Aro vd., 2009:163; Çetin, 2004:90). Bu nedenle, özellikle tükenmişlik riski yüksek meslek alanlarında konuya ilişkin analizlerin yapılması ve gereken önlemlerin alınması önem arz etmektedir. Bu bağlamda, hemşirelerin tükenmişlik düzeylerinin tespiti ve işlerini bırakma eğilimleri üzerindeki etkilerinin incelenmesi bu makalenin amacını oluşturmaktadır.

\section{Kavramsal Çerçeve}

Bu bölümde tükenmişlik ve alt boyutları ile ilgili açıklamalar yapıldıktan sonra, işten ayrılma niyeti kavramı incelenecek; sonra da tükenmişlik sendromunun sağlık çalışanlarının işten ayrılma niyetleri üzerindeki etkileri konusunda yapılan araştırma örneklerine yer verilecektir. 


\subsection{Tükenmişlik Kavramı ve Boyutları}

"Tükenmişlik, içinde bulunduğumuz çağın toplumsal yaşantısının neticesidir ve hayatımızı anlamlandırma çabamız sonucunda meydana gelen bir olgudur" (Şıklar ve Tunalı, 2012: 76). "Meslek otizmi", "ruhen çöküş", "psikolojik ve fizyolojik açıdan enerjinin düşüşü", "iş yaşantısı ve özel yaşantı arasında stresle baş etmede yetersizlik" gibi ifadelerle nitelendirilen tükenmişlik sendromu "başarısız olma, yıpranma, enerji ve güç azalması neticesinde kişinin taleplerini karşılamada güçlük yaşaması ve içsel motivasyonunda ciddi düşüş meydana gelmesi" (Dolgun, 2012: 288; Barutçu ve Serinkan, 2008:54) şeklinde de ifade edilmektedir. Tükenmişlik kavramı 1970'li yıllarda Freudenberger (1974) ve Maslach (1976) tarafından psikososyal alanyazında ilk kez tanımlanmış; bireylerin çalışma hayatındaki performansını negatif etkilemesi nedeniyle örgütlerde sosyal bir sorun olarak incelenmeye başlanmış ve daha sonraları çeşitli ülkelerde, değişik sektörlerde -multidisipliner bir çalışma alanı olarak sağlık, eğitim, işletmecilik ilk sıralarda olmak üzerebirçok araştırmacı tarafından konunun araştırılması yaygınlaştırılarak günümüze kadar devam etmiştir (Kristensen vd., 2005:192-193). Kavramla ilgili olarak en kapsamlı çalışma Christina Maslach tarafından yapılmış ve -bu çalışmada da kullanılan- Maslach Tükenmişlik Ölçeği'ni (1981) alanyazına kazandırmıştır.

Tükenmişlik kavramı, "özellikle yaptığı işin gerektirdiği yoğun duygusal beklenti ve isteklere maruz kalan ve daimi olarak başkalarıyla yüz yüze şekilde çalışmak durumunda olan kişilerde rastlanan uzun süreli yorgunluk, fiziksel bitkinlik, umutsuzluk ve çaresizlik temelli duygularının, hayata, yaptıkları işe ve başkalarına karşı negatif şekilde yansıması sonucu oluşan bir sendrom" olarak tanımlanmış ve "duygusal tükenme", "duyarsızlaşma" ve "kişisel başarı hissinde azalma" şeklinde üç boyutta değerlendirilen psikolojik duygu durumu olarak ele alınmıştır (Maslach ve Jackson, 1981:99; Maslach, vd. 2001:398). Bu boyutlar aşağıda kısaca tanımlanmıştır.

Duygusal Tükenme: Tükenmişlik sendromunun kişisel ve stresle ilişkili yönünü belirtmekte ve kişinin fiziksel ve duygusal enerjisinde düşüş meydana gelmesini anlatmaktadır (Budak ve Sürgevil, 2005:96). Maslach'a göre tükenmişliğin kilit faktörü duygusal tükenmişliktir. Duygusal tükenmişlik, zaman içinde enerji azalmasına, kronik yorgunluğa ve fiziksel açıdan tükenmeye sebebiyet vermektedir (Skaalvik ve Skaalvik, 2009:518). Öte yandan duygusal tükenme yaşamaya başlayan bireyler tükenmişliğin yoğun stres etkisiyle birlikte duygusal ve fiziksel anlamda kendilerini yıpranmış ve bitkin hissetmekte ve zamanla hizmet sundukları insanlara karşı düşük sorumluluk yaklaşımı göstermeye başlamaktadırlar (Ardıç ve Polatçı, 2009:23). Sendromun bu boyutla başlayıp, devamında duyarsızlaşma ve sonrasında da kişisel başarı hissinde azalma şeklinde ilerlediği ifade edilmektedir.

Duyarsızlaşma: En yalın anlatımla duyarsızlaşma, bireyin işi gereği iletişim halinde olduğu insanlara karşı bilinçli mesafeli davranması, onları umursamaması olarak ifade edilebilir (Maslach vd., 2001:403). Tükenmişlik yaşayan bireyler yalnız kalmayı ve diğer insanlardan uzaklaşmayı içtenlikle isterler. Bu anlamda duyarsızlaşma, tükenmişliğin bireyler arası boyutunu oluşturmakta ve "bireylere karşı tepkisizleşme hali" ve bir nevi "bireyin dış dünyaya karşı duvar örmesi" şeklinde de ifade edilmektedir. Duyarsızlaşma sendromu yaşayan bireyler, hizmet sundukları insanlara karşı alaycı, sert, aşağılayıcı ve kaba davranışlar gösterebilirler; onların rica ve taleplerini dikkate almayabilirler; aldırmaz ve umursamaz davranışlar sergileyip, sorun çözme yerine, katı ve kuralcı hareketlerde bulunabilirler (Sürgevil, 2014:66).

Kişisel Başar Hissinde Azalma: Çevresindeki insanlara karşı negatif duygu içerisinde olan tükenmiş birey, onların kendisini sevmediği ve güvenmediği kanaatine varır; onlara ilgi gösterme ve hizmet sunma konusunda yetersizlik hisseder ve bu duygunun neticesinde de kendisi hakkında "başarısız" hükmünü verir. Sonuç olarak yaptığı işte ilerleme kaydedemediğini düşünerek özgüvenini ve özsaygısını yitirmesine neden olur; uğraş vermesinin boşuna olduğunu düşünerek çabalamayı bırakır (Skeja, 2012:12-13).

Hemşirelik yoğun stres yaşanan bir meslektir. Gerek hasta yakınlarıyla iletişim sorunlarının yaşanması, gerekse hastalara bakım ve duygusal destek vermek durumunda kalınması, onlar üzerinde önemli düzeyde stres yaratmaktadır. Bu sorunları çözümlemede enerji düşüklüğü yaşanmakta, yetersizlik duygusu ile birlikte duygusal açıdan tükenmeye dönüşerek hastalara karşı soğuk ve ilgisiz davranmalarına sebebiyet vermektedir. Ayrıca kendini işine verememesi mesleğinde hata ve kazalar yapmasına neden olabilmektedir (Baduroğlu, 2010:15; Meydan vd., 2011:178). Bütün bunlara ek olarak, bağımsız çalışamamaları, beklentilerinin karşılanmaması, eksik malzeme ile çalışmak durumunda kalmaları, uzun ve vardiyalı çalışma saatleri, belirsiz görev tanımları, ödüllendirmede yetersizlikler, yüksek iş temposu, düşük ücret vb. faktörler 
hemşirelerin stres düzeylerini arttırarak tükenmişlik sendromu yaşamalarına yol açmaktadır (Kemeröz, 2017:19).

\section{2. İşten Ayrılma Niyeti}

İşten ayrılma niyeti, işgörenlerin çalıştıkları örgütteki koşullardan kaynaklı memnuniyetsizlik nedeniyle "işten vazgeçme" niyeti taşımaları anlamına gelmektedir. Rusbelt vd.'ne (1988) göre "işten ayrılma niyeti, istihdam koşullarından memnun olmamaları nedeniyle çalışanların göstermiş oldukları yıkıcı ve aktif bir tavırdır" (Rusbelt vd., 1988: 599). Tett ve Meyer (1993: 259) ise kavramı, "bireyin işine veya işyerindeki şartlarına bağlı gelişen, bilinçli ve kasıtlı azalmış çalışma arzusu" şeklinde tanımlamışlardır.

İşten ayrılma kavramı, -gönüllü ayrılma isteği olsa da- negatif algı yaratmakta ve iş tatminsizliğini çağrıştırmaktadır. Nitekim, Takase vd. tarafından 2005 yılında yapılmış olan çalışmada, iş tatmini ile işten ayrılma niyeti arasında negatif bir ilişkinin olduğu ortaya konmuştur (Onay ve Kılcı, 2011:363).

İşgörenlerin işten ayrılma niyeti üzerinde etkili olan faktörler üç başlık altında toplanmaktadır; bireysel özellikler (kişilik özellikleri, işe karşı tutum, yaş, cinsiyet, medeni durum, evlilik, ölüm, emeklilik, psikolojik ve fiziksel nedenler vb.), örgütsel nedenler (örgüt kültürü, örgüt iklimi, çalışma koşullarının ağırlığı, iş güvencesinin olmaması, örgütsel adaletsizlikler, çalışma arkadaşları ve üstleriyle iletişimsizlik veya olumsuz ilişkiler, kariyer geliştirme olanaklarının zayıflığı, sosyal hakların azlığı, düşük ücret vb.) ve ekonomik ve sosyal nedenlerle meydana gelen bir takım çeoresel faktörler sayılabilir (Polat ve Meydan, 2010:145; Çarıkçı ve Çelikkol, 2009:153).

Sağlık çalışanları içinde en büyük grubu oluşturan ve hasta ile birlikte uzun süreli çalışan hemşireler, çalışma ortamındaki ciddi boyutlardaki olumsuz koşullardan en çok etkilenen sağlık çalışanları olarak kabul edilmektedir (Karwowski vd., 2005:19). Bu negatif durumlar hemşirelerde hizmet kalitesini etkileyerek verimin azalmasına neden olmakta, onları tükenmeye, duyarsızlaşmaya, mesleği bırakmaya ya da işyerinden ayrılmaya yöneltmektedir (Kebapçı ve Akyolcu, 2011:63).

İşten ayrılma niyetinin iş görenler, örgütler ve toplum açısından negatif sonuçları bulunmaktadır. İşgören açısından, psikolojik sorunlar, yeni bir iş bulma ve işe adaptasyon, gelirinde düzensizlik, ailevi sorunlar ve işe yönelik kazanımların hebâ olması; örgüt açısından, işten ayrılma gerçekleştiğinde yeni işgören bulmaeğitme, işin aksaması; toplum açısından ise üretim kaybı ve iş kaybı gibi sorunlara sebebiyet vermektedir (Avcı ve Küçükusta, 2009:37). Bu çalışmanın konusu olan tükenmişlik, işten ayrılma niyetine yol açan ve işten ayrılmaya sebebiyet veren önemli bir sorun olarak karşımıza çıkmakta ve sağlık kurumları başta olmak üzere birçok hizmet sektörü çalışma alanlarında yoğunlukla gözlenmektedir.

\subsection{Tükenmişlik ve İşten Ayrılma Niyeti}

Çalışma psikolojisi disiplininde sıklıkla konu edilen tükenmişlik sendromu, ilişkili birçok değişkenle beraber araştırılmaya çalışılmaktadır. Türkiye'de ve dünyada gerek sağlık sektöründe gerekse diğer sektörlerde çalışanların tükenmişlik düzeylerini, işten ayrılma niyetlerini ve aynı zamanda her iki kavramın birbirleriyle ilişkilerini ortaya koymaya yönelik çok sayıda ampirik araştırma bulunmaktadır.

Hemşirelerin çalıştıkları kurumdan ayrılma niyetini tespite yönelik Heinen vd.'nin (2013) 10 Avrupa ülkesini kapsayan araştırmalarında hemşirelerin işyerlerinden ayrılma niyetlerinin \%19 ile \%49 arasında değiştiği; Gardulf vd. (2005) tarafından İsveç'te yapılan aynı konulu araştırmada \%54; Mc Carthy vd.'nin (2007) İrlanda'da yaptığı incelemede hemşirelerin işten ayrılma niyetinin \%60 gibi yüksek bir oranda olduğu bulgulanmıştır. Falgueras (2015:26) tarafından yapılan ve Barselona'da birinci basamak sağlık ekiplerini kapsayan çalışmada tükenmişliği oluşturan boyutlardan (duygusal tükenme, duyarsızlaşma ve kişisel başarı hissinde azalma) en az bir tanesinin görülme oranı \%46 olarak belirlenmiştir.

Cortese'nin (2012) İtalya'da sağlık kurumlarında çalışan yoğun bakım ünitesi hemşireleri üzerinde yaptığı araştırmada; görev aldığı birimden ayrılma niyetinin \%41,8, görev yaptığı hastaneden ayrılma niyetinin $\% 21,9$, meslekten (hemşirelikten) ayrılma niyetinin ise \%14,6 olduğu sonucuna ulaşılmıştır. Ribeiro (2014:6) ise Brezilya'da bir hastanede yaptığı çalışmada hemşirelerde tükenmişlik sendromunun görülme oranı \%10.1 düzeyinde çıkmıştır. 
Sayıl vd., (1997), hemşire ve doktor grubuna Maslach Tükenmişlik ölçeği uygulayarak yapmış oldukları çalışma sonuçlarına göre, hemşireler ve doktorlar arasında duygusal tükenme düzeylerinde anlamlı farklılıklar saptanmış, hemşirelerin daha çok duygusal tükenmeye maruz kaldıkları tespit edilmiş, duyarsızlaşma ve düşük kişisel başarı hissi alt ölçeklerinde ise farklılık bulunamamıştır.

Demir'in (1999) yaptığı araştırmada ise; çalışılan ortamda hemşire ve araç gereç sayısının yeterli olması halinde tükenmişlik düzeyinin azaldığı, diğer taraftan mesleki deneyim kazandıkça duygusal tükenme ve duyarsızlaşma ile mücadelenin kolaylaştı̆̆ı bulgularına ulaşılmıştır. Karadağ vd. (2001), ekonomik sorunlara maruz kalan hemşirelerin daha yüksek düzeyde duygusal tükenme yaşadıklarını tespit etmişlerdir.

Ayrıca araştırmalar, genç ve nispeten hizmet süresi daha kısa olan hemşirelerin işlerinden ayrılma niyetlerinin daha güçlü (Gieter vd., 2011:1567) olduğunu göstermektedir. Ülkemizde yapılan çalışmada ise, Y Kuşağ1 hemşirelerinin meslekten ayrılma niyetinin $\% 45,8$ gibi yüksek düzeyde olduğu (Şen Bezirci ve Kocaman, 2013) saptanmıştır.

Çalışkan ve Pekkan'ın (2019), 526 sağlık çalışanından topladıkları verilerle yapmış oldukları çalışmada, sağlık çalışanlarında tükenmişlik duygusunun var olduğunu, tükenmişlik sendromunun üç alt boyutu olan duygusal tükenme, duyarsızlaşma ve kişisel başarı hissinde azalmanın işten ayrılma niyeti üzerinde pozitif ve istatistiksel açıdan anlamlı ilişkiler bulgulamışlardır.

Çetin Aydın vd. (2021), tarafından devlet hastanesinde görev yapan 263 hemşireden toplanan verilerin değerlendirilmesiyle; işten ayrılma niyetini, stres, tükenmişlik ve işe ilişkin duyguların anlamlı bir şekilde etkilediğini tespit etmişlerdir.

\section{Yöntem}

\subsection{Araştırmanın Modeli}

Bu çalışmada, sağlık kurumlarında çalışan hemşirelerin tükenmişlik sendromlarının işten ayrılma niyeti üzerindeki etkilerinin ölçülmesi amaçlanmaktadır. Tükenmişlik seviyesi yüksek olan işgörenlerin performanslarında azalma, işe devamsızlıkta artış, örgütsel bağlılıkta azalma, ilişkilerde bozulma ve işten ayrılma kararlarında artış görülebilmektedir. Hangi sebepten kaynaklı olursa olsun, bireyin kendi iradesiyle işi bırakmasına sebebiyet verebilecek olan bu niyetin, işten ayrılma davranışına dönüşmeden örgüt yöneticilerince tespit edilerek engellenmesi gerekir; bu nedenle, tükenmişlik ve işten ayrılma niyetinin incelenmesiyle alanyazına katkı sağlamak çalışmanın önemini ortaya koymaktadır.

Kuramdan ve ampirik araştırmalardan yola çıkılarak oluşturulan hipotezler aşağıda sunulmuştur. Bu bağlamda yapılandırılan araştırma modeli Şekil 1' de görülmektedir.

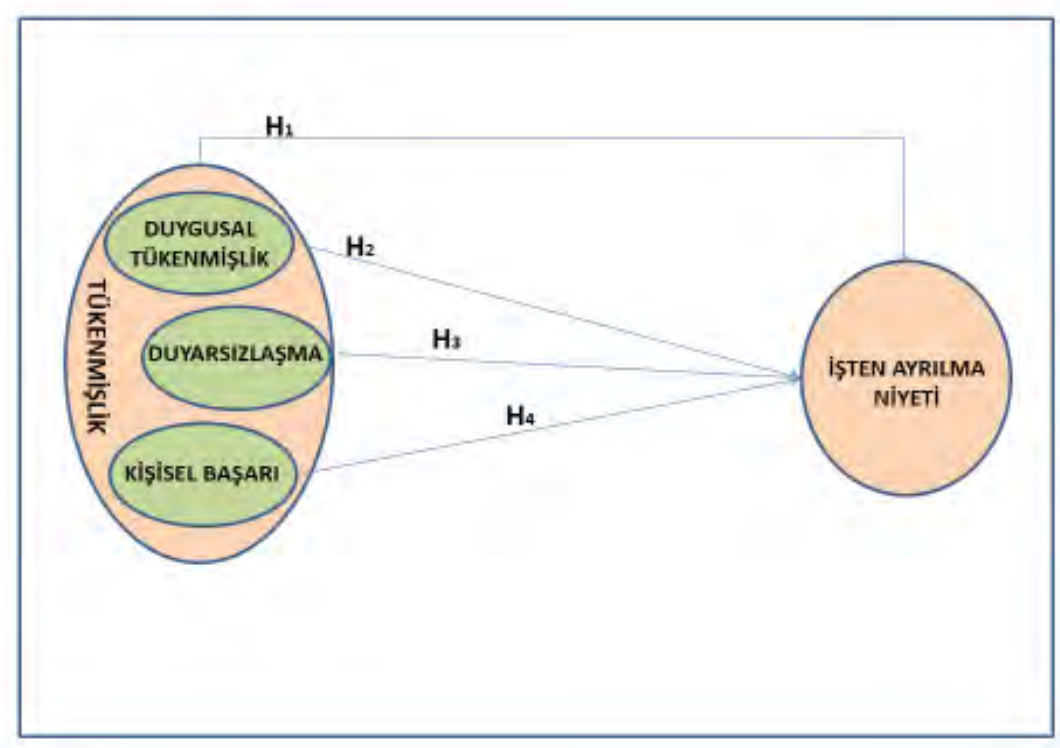

Şekil 1: Araştırma Modeli 
Araştırmanın test etmek amacıyla oluşturulan 4 hipotezi aşağıdaki şekildedir:

H1: Sağlık kurumlarında çalışan hemşirelerin tükenmişlik düzeyleri işten ayrılma niyetlerini pozitif ve anlamlı şekilde etkiler.

$\mathbf{H}_{2}$ : Sağlık kurumlarında çalışan hemşirelerin duygusal tükenmişlik düzeyleri işten ayrılma niyetlerini pozitif ve anlamlı şekilde etkiler.

H3: Sağlık kurumlarında çalışan hemşirelerin duyarsızlaşma düzeyleri işten ayrılma niyetlerini pozitif ve anlamlı şekilde etkiler.

$\mathbf{H}_{4}$ : Sağlık kurumlarında çalışan hemşirelerin kişisel başarı düzeyleri işten ayrılma niyetlerini negatif ve anlamlı şekilde etkiler.

\subsection{Evren ve Örneklem}

Araştırmada, Adana ve Mersin'deki sağlık kurumlarında çalışmakta olan hemşireler çalışmanın evrenini oluşturmaktadır. Alanyazında belirtildiği üzere örneklem sayısının yeterliliği, istatistiksel olarak hesaplanmaktadır. 0,95 güven aralığı ve 0,05 örneklem hatasıyla temsil edilebilecek olan evren büyüklügüne bağlı örneklem sayıları aşağıda Tablo 1'de verilmiştir.

Tablo 1. Araştırmanın Evrenine Göre Örneklem Sayısı

\begin{tabular}{lcccccccccc}
\hline Evren Büyüklüğü & 100 & 150 & 250 & 500 & 1000 & 5000 & 10000 & 50000 & 100000 & 1000000 \\
\hline Örneklem Sayısı & 80 & 108 & 152 & 217 & 278 & 357 & 370 & 381 & 383 & 384 \\
\hline
\end{tabular}

Kaynak: Yazıcıŏglu ve Erdoğan, 2014: 89

Adana ve Mersin'de çalışan hemşirelerin tam sayısı bilinmediği için en üst değer olan 1000000 dahi olsa bu çalışmanın örneklem sayısının 464 olması yeterli kabul edilmektedir.

\subsection{Veri Toplama Arac1}

Araştırmada veri toplama yöntemi olarak nicel araştırma yöntemlerinden anket tekniği kullanılmıştır. Anket, çevrimiçi yapılacak şekilde tasarlanmış olup, ücretsiz web sitesi hizmeti olan Google Forms üzerinden -mobil telefonlar aracılığıyla da cevaplanabilecek özellikte- düzenlenmiştir. Anket bağlantısı 10 Eylül- 10 Ekim 2021 tarihleri arasında -zincir (kartopu) örnekleme yöntemi kullanılarak- e-posta ve mobil telefon mesaj uygulamaları aracılığıyla katılımcılara gönderilmiş, çevrelerindeki diğer hemşirelere iletmeleri istenmiştir. 464 katılımcının cevapladığı anket çalışmasında en önemli kısıt, diğer illeri kapsamamış olması, içinde bulunduğumuz Covid-19 salgın sürecinde sağlık kurumlarında çalışan hemşirelerin aşırı yoğun olmaları benzer anket çalışmalarının da artması- nedeniyle anket cevaplamaya zaman ayıramamaları söylenebilir.

Sağlık kurumlarında çalışan hemşirelerin Tükenmişliklerinin (TÜK) ve tükenmişliğin alt boyutları olan, Duygusal Tükenmişlik (DT), Duyarsızlık (DYR) ve Kişisel Başarının (KBA), bireylerin İşten Ayrılma Niyetleri (İAN) üzerine etkisini tespit amaçlı bu çalışmada yararlanılan ölçeklere ilişkin bilgiler aşağıda verilmektedir.

Tükenmişlik Ölçeği (TUK): Soru formunda sağllk kurumunda çalışan hemşirelerin tükenmişlik seviyelerinin ölçülmesi amacı ile Maslach ve Jackson (1981) tarafından geliştirilmiş olan ve Türkçeye uyarlaması ile geçerlilik ve güvenilirlik çalışmaları Ergin (1992) tarafından gerçekleştirilen Maslach Tükenmişlik Ölçeği kullanılmıştır. Çalışmada beşli Likert ölçeği kullanılarak; (1) Hiç, (2) Nadiren (3) Bazen, (4) Çoğu Zaman ve (5) Her Zaman şeklinde değerlendirme yapılması istenmiştir. Ölçek toplamda 22 madde ve üç alt boyuttan oluşmaktadır. Bu alt boyutlardan "duygusal tükenme" 9 madde, "duyarsızlaşma" 5 madde ve "düşük kişisel başarı hissi" 8 maddeden oluşmaktadır. Yapılan güvenirlik analizi sonucunda tükenmişlik ölçeğinin toplam Cronbach alfa güvenirlik katsayısı .84 olarak, tükenmişliğin alt boyutlarını içeren duygusal tükenmişlik, duyarsızlık ve kişisel başarı ölçeklerin Cronbach alfa güvenirlik katsayıları sırasıyla, .92, .74, .83 olarak bulunmuştur.

İşten Ayrılma Niyeti Ölçeği (İAN): Sağlık kurumunda çalışan hemşirelerin algıllanan işten ayrılma niyetlerinin ölçülmesi amacı ile Rosin ve Korabik'e (1991) ait 4 maddelik ölçekten (TIS-Turnover Intension Scale) 
yararlanılmıştır. Ancak Covid-19 salgın sürecinin işten ayrılma niyeti üzerinde ne derece etki ettiğinin ayıklanabilmesi için "İşimi bırakmayı son 1 yıl içinde düşünmeye başladım" ifadesi eklenerek 5 madde şeklinde uygulanmıştır. İşten Ayrılma Niyeti ölçeği de "(1) Kesinlikle Katılmıyorum - (5) Kesinlikle katılıyorum" ifade aralığında beşli Likert şeklinde tasarlanmıştır Bu ölçeğin de güvenirlik analizi yapılmış ve Cronbach alfa güvenirlik katsayısı .88 olarak hesaplanmıştır.

\subsection{Verilerin Analizi}

Sağlık kurumlarında çalışan hemşirelerin tükenmişliklerinin (TÜK) alt boyutları olan, Duygusal Tükenmişlik (DT), Duyarsızlık (DYR) ve Kişisel Başarının (KBA), bireylerin İşten Ayrılma Niyetleri (İAN) üzerine etkisini tespit etmeye yönelik olarak yapılan bu araştırmada, ilk başta örneklem ve kullanılan ölçeklere ilişkin bilgilendirmeler yapılmıştır. Araştırma ile ortaya koyulan bilgilerle oluşturulan modele ilişkin, SPSS ve AMOS programında analizler yapılmıştır. Bu amaçla, değişkenler arası korelasyonlar hesaplanmış, sonrasında ise regresyon analizleri ile hipotezler test edilmiştir. Tüm bu analizler neticesinde ulaşılan bulgular mevcut alanyazın ile karşılaştırılarak araştırmacılara ve yöneticilere önerilerde bulunulmuştur.

\section{Bulgular}

Araştırma evrenini oluşturan -Adana ve Mersin'de faaliyet gösteren sağlık kurumu çalışanı- hemşirelerin demografik özellikleri aşağıda verilmiştir. Araştırmaya katılanların: 41' i erkek (\% 0.09) ve 423' ü bayan (\% 91.1), 287' si evli (\% 61.9), 177' si bekar (\% 38.1), \%43.6's 35 yaş ve altında, \%45.5'i 5 yıl ve altında çalışma süresine sahip, 39’ u (\% 0.08) önlisans, 277' si (\% 59.7) lisans, ve 148' i (\% 31.9) lisansüstü eğitim mezunu, 335'i (\% 72.2) kamuda, 129'u (\% 27.8) özel sektörde yer almaktadır.

Araştırma neticesinde elde edilen verilere SPSS ve AMOS programında analizler yapılmıştır. Bu kapsamda, ilk önce anket katılımcılarının algıladıkları tükenmişlik düzeyleri ve tükenmişliğin alt boyutları olan "duygusal tükenmişlik", "duyarsızlaşma" ve "düşük kişisel başarı hissi" ile bu değişkenlerin etkisinin olduğu düşünülen işten ayrılma niyeti ile ilgili değişkenlere yönelik elde edilen verilerin ortalamaları, standart sapmaları ve aralarındaki korelasyonlar incelenmiştir. Analizin bir sonraki aşamasında ise bu değişkenler arasındaki etkileşimin olup olmadığını anlamak için regresyon analizleri yapılmıştır. Yapılan analiz neticesinde hesaplanan ortalamalar, standart sapmalar ve korelasyon değerleri Tablo 2' de verilmektedir.

Tablo 2. Verilere İlişkin Ortalama, Standart Sapma ve Korelasyon Değerleri

\begin{tabular}{cccccccc}
\hline & Ort. & S.S. & 1 & 2 & 3 & 4 & 5 \\
\hline 1. TÜK & 3.16 & .55 & $(.84)$ & & & & \\
\hline 2. DT & 3.19 & .99 & $.86^{* *}$ & $(.92)$ & & & \\
\hline 3. DYR & 2.42 & .84 & $.84^{* *}$ & $.68^{* *}$ & $(.74)$ & & \\
\hline 4. KBA & 3.87 & .64 & $.15^{* *}$ & $-.22^{* *}$ & $-.21^{* *}$ & $(.83)$ & \\
\hline 5. İAN & 2.57 & 1.23 & $.53^{* *}$ & $.64^{* *}$ & $.50^{* *}$ & $-.27^{* *}$ & $(.88)$ \\
\hline
\end{tabular}

${ }^{*} \mathrm{p}<.05{ }^{* *} \mathrm{p}<.01$

Tablo 2'den de anlaşılacağı üzere tüm bağımlı ve bağımsız değişkenler arasında ilişkiler anlamlı bulunmaktadır. Bu sebeple değişkenler arasında önemli etkiler öngörülebilmektedir.

Bağımlı değişkenler üzerinde bağımsız değişkenlerin açılama güçlerini ortaya koymak maksadıyla regresyon analizleri yapılmıştır. Regresyon analizlerinde, İşten Ayrılma Niyeti (İAN) bağımlı değişken olarak ele alınmış, Tükenmişlik (TÜK) ve tükenmişliğin alt boyutları olan, Duygusal Tükenmişlik (DT), Duyarsızlık (DYR) ve Kişisel Başarı (KBA), bağımsız değişken olarak ele alınmış ve bağımlı değişken üzerindeki etkileri incelenmiştir. 
Regresyon analizlerinin ilk aşamasında hemşirelerin tükenmişlik algısı bir bütün olarak ele alınarak, bağımlı değişken işten ayrılma niyeti üzerindeki etkileri incelenmiştir. Sonuçlar değerlendirildiğinde, Tablo 3'de de görüldügü gibi tükenmişliğin, bağımlı değişken işten ayrılma niyeti üzerinde anlamlı ve pozitif bir etkiye sahip olduğu görülmektedir. Bu kapsamda Hipotez 1 onaylanmıştır.

Tablo 3. Basit Regresyon Analizleri

İşten Ayrılma Niyeti

\begin{tabular}{lllll}
\hline Değişkenler & $\boldsymbol{R}^{2}$ & Düz. $\boldsymbol{R}^{2}$ & $\boldsymbol{F}$ & $\beta$ \\
\hline Tükenmişlik & .283 & .281 & $182.1^{* *}$ & $.532^{* *}$ \\
\hline
\end{tabular}

${ }^{* *} p \leq .01$

Regresyon analizlerinin ikinci aşamasında tükenmişliğin alt boyutları olan, duygusal tükenmişlik, duyarsızlık ve düşük kişisel başarının, bağımlı değişken işten ayrılma niyeti üzerindeki etkileri incelenmiştir. Sonuçlar değerlendirildiğinde, Tablo 4'te de görüldügü gibi duygusal tükenmişlik ve duyarsızlığın bağımlı değişken işten ayrılma niyeti üzerinde anlamlı ve pozitif bir etkiye sahip olduğu ve üçüncü boyut olan kişisel başarının, bağımlı değişken işten ayrılma niyeti üzerinde anlamlı ve negatif bir etkiye sahip olduğu görülmektedir. Bu kapsamda Hipotez 2, 3 ve 4 onaylanmış olmaktadır. Tablo 5'te ise araştırmanın hipotez sonuçları yer almaktadir.

Tablo 4. Basit Regresyon Analizleri

İşten Ayrılma Niyeti

\begin{tabular}{lllll}
\hline Değişkenler & $\boldsymbol{R}^{2}$ & Düz. $\boldsymbol{R}^{2}$ & $\boldsymbol{F}$ & $\boldsymbol{\beta}$ \\
\hline Duygusal Tükenmişlik & .413 & .411 & $324.4^{* *}$ & $\mathbf{. 6 4 2 ^ { * * }}$ \\
Duyarsızlık & .245 & .243 & $149.7^{* *}$ & $\mathbf{. 4 9 5 ^ { * * }}$ \\
Kişisel Başarı & .072 & .070 & $35.80^{* *}$ & $\mathbf{- . 2 6 8 ^ { * * }}$ \\
\hline
\end{tabular}

${ }^{*} \mathrm{p}<.05,{ }^{* *} p \leq .01$

Tablo 5. Hipotez Testi Sonuçları

\begin{tabular}{|l|c|}
\hline \multicolumn{1}{|c|}{ HIPOTEZLER } & SONUÇ \\
\hline $\begin{array}{l}\text { H: Sağlık kurumlarında çalışan hemşirelerin tükenmişlik düzeyleri işten ayrılma } \\
\text { niyetlerini pozitif ve anlamlı şekilde etkiler. }\end{array}$ & Onaylandı \\
\hline $\begin{array}{l}\text { H2: Sağlık kurumlarında çalşan hemşirelerin duygusal tükenmişlik düzeyleri işten } \\
\text { ayrılma niyetlerini pozitif ve anlamlı şekilde etkiler. }\end{array}$ & Onaylandı \\
\hline $\begin{array}{l}\mathbf{H}_{3} \text { Sağlık kurumlarında çalışan hemşirelerin duyarsızlaşma düzeyleri işten ayrılma } \\
\text { niyetlerini pozitif ve anlamlı şekilde etkiler }\end{array}$ & Onaylandı \\
\hline $\begin{array}{l}\text { H4: Sağlık kurumlarında çalışan hemşirelerin kişisel başarı düzeyleri işten ayrılma } \\
\text { niyetlerini negatif ve anlamlı şekilde etkiler }\end{array}$ & Onaylandı \\
\hline
\end{tabular}

Yapılan çalışmalarda, her ne sebeple olursa olsun hizmet verdiği sağlık kurumlardan ayrılma niyetinde olan ve muvafakat almaya çalışan hemşirelerin sayısı her geçen gün artmaktadır. Sağlık kurumlarında çalışan hemşirelerin önemli oranda işten ayrılma niyetinde olması, hasta bakımı hizmet niteliğini ve sürekliliğini etkilemekte, dolayısıyla kurumun verimliliğini aşağı çekmektedir (Abaan ve Duygulu, 2004:66). Araştırmaya katılan hemşirelerin işten ayrılma niyetini belirleme amacıyla sorulan ifadelere vermiş oldukları yanıtların 
oransal dağılımı Tablo 6'da görülmektedir. "Kariyerimin şu anında, mümkün olsaydı işimi bırakırdım" ifadesine katılanların oranı \%45.8 (213) gibi oldukça yüksek bir düzeyde çıkmıştır. İfadeye katılan hemşirelerin \%55.7'si 35 yaş ve altında, \%63.4'ü ise 5 yıl ve daha az hizmet süresine sahip grubu oluşturmaktadır.

Tablo 6. Ankete Katılan Hemşirelerin İşten Ayrılma Niyetlerinin Oransal Dağılımı ( $\mathrm{n}=464)$

\begin{tabular}{|l|c|c|c|c|c|}
\hline İfadeler & $\begin{array}{l}\text { Kesinlikle } \\
\text { katılmıorum }\end{array}$ & Katılmıyorum & Kararsızım & Katılıyorum & $\begin{array}{l}\text { Kesinlikle } \\
\text { katılıyorum }\end{array}$ \\
\hline $\begin{array}{l}\text { Kariyerimin şu anında, mümkün } \\
\text { olsaydı işimi bırakırdım }\end{array}$ & $\% 25,5$ & $\% 14,6$ & $\% 14,2$ & $\% 12,6$ & $\% 33,2$ \\
\hline $\begin{array}{l}\text { Önümüzdeki altı ay içerisinde } \\
\text { işimi bırakmayı düşünüyorum }\end{array}$ & $\% 45,4$ & $\% 16,4$ & $\% 17,9$ & $\% 8$ & $\% 12,4$ \\
\hline Şu anda yeni bir iş arıyorum & $\% 54,1$ & $\% 17,9$ & $\% 11,5$ & $\% 5,1$ & $\% 11,5$ \\
\hline İşimi bırakmayı düşünüyorum & $\% 38,4$ & $\% 17,1$ & $\% 16,9$ & $\% 10,2$ & $\% 17,3$ \\
\hline $\begin{array}{l}\text { İşimi bırakmayı son 1 yll içinde } \\
\text { düşünmeye başladım }\end{array}$ & $\% 32,8$ & $\% 15,3$ & $\% 13,8$ & $\% 14$ & $\% 24$ \\
\hline
\end{tabular}

Tüm dünyada ve Türkiye'de, 2020 yılından beri büyük mücadeleler verilen Covid-19 salgın sürecinde, her kademeden sağlık çalışanlarının iş yükü, stresi ve tükenmişlik düzeyi ciddi şekilde artmış, yüksek derecede özveri ile çalışmak durumunda kalmışlardır. Bu sebeple araştırmada kullanılan ve Rosin ve Korabik'e (1991) ait 4 maddelik ölçeğe, "İşimi bırakmayı son 1 yıl içinde düşünmeye başladım" ifadesi eklenerek 5 madde şeklinde uygulanmıştır. Bu ifadeye katılım gösteren hemşirelerin oranı \%38 (176) düzeyindedir. Bu sonuç da, salgın sürecinde sağlık kurumu çalışanlarının tükenmişlik düzeylerinde, dolayısıyla işten ayrılma niyetlerinde önemli sayılabilecek artış gözlemlendiğini ortaya koymaktadır.

\section{Sonuç ve Tartışma}

$\mathrm{Bu}$ araştırmada, Adana ve Mersin'de sağlık kurumlarında çalışan hemşirelerin tükenmişlik algılarının işten ayrılma niyeti üzerinde etkilerinin olup olmadığı ortaya konmaya çalışılmıştır. Araştırma kapsamında tasarlanan hipotezleri analiz edilebilmek için ihtiyaç duyulan bilgiler, Adana ve Mersin'deki kamu ve özel sektör sağllk kurumlarında çalışan hemşirelerden, çevrimiçi metotla, kartopu örneklemesi yöntemiyle ve bu çalışma için dizayn edilmiş olan anket formu aracılığıyla toplanan verilerden oluşmaktadır. 464 anketle sağlanan verilere uygulanan analizlerin sonuçları, araştırma için oluşturulan hipotezlerin tamamının desteklendiği gerçeğini ortaya koymaktadır.

Alanyazında, tükenmişlik algılarının işten ayrılma niyetine etkisini inceleyen çok sayıda ulusal ve uluslararası çalışma yapılmış, iki değişken arasında pozitif yönlü ve anlamlı bir ilişki tespit edilmiştir. Bu çalışmada, bireylerin duygusal tükenmişlik ve duyarsızlaşma düzeylerinin bağımlı değişken işten ayrılma niyeti üzerinde anlamlı ve pozitif bir etkiye sahip olduğu ve üçüncü boyut olan kişisel başarının, bağımlı değişken işten ayrılma niyeti üzerinde anlamlı ve negatif bir etkiye sahip olduğu görülmektedir. Elde edilen bu sonucun, alan yazında yapılmış olan çalışmalarla (Çalışkan, A. ve Özkan H., 2020; Sayıl vd., 1997; Cortese, 2012; Heinen vd.,2013; Mc Carthy vd., 2007; Gardulf vd., 2005; Ribeiro, 2014; Karadağ vd., 2001; Çalışkan, ve Bekmezci, 2019; Çalışkan, ve Pekkan, 2019) desteklendiği görülmektedir.

Ayrıca, “Kariyerimin şu anında, mümkün olsaydı işimi bırakırdım” ve "İşimi bırakmayı son 1 yıl içinde düşünmeye başladım" ifadelerine verilen cevaplara, genç ve meslekte hizmet süresi az hemşirelerde nispeten yüksek katılımın görülmesi de alanyazında bu konuda yapılan çalışmalardan elde edilen sonuçlarla (Flinkman vd., 2008; Takase, 2010; Şen Bezirci ve Kocaman 2013; Lavoie vd., 2011; Hayes vd., 2012; Gieter vd.,2011; Sürer ve Kocaman, 2009; Pathman vd.,2002) benzerlik göstermektedir. Bu araştırmalardan elde edilen sonuçlar yaş ve kıdem değişkenlerinin işten ayrılma niyeti üzerinde önemli derecede etkisi olduğunu ortaya koymaktadır.

Sağlık çalışanlarının çalıştıkları kurumlara duydukları bağlılık, -diğer örgütsel değişkenlerde olduğu gibisağlık bakım çıtılarına direkt etki etmektedir. Tükenmişliğin negatif etkilerini giderebilmek, en azından 
asgari düzeye indirebilmek için alınması gereken önlemler, bireysel ve örgütsel olmak üzere iki grupta ele alınmalıdır. Her şeyden önce hemşirelerin, verdikleri hizmetin doğasında stres faktörünün yer aldığının farkında olmaları gerekmektedir. Kişi, stresin farkında olduğunda, onu kabullenme, tanımlama, baş etme ve yönetme konusunda daha kararlı davranacaktır. Bu nedenle bireysel çaba ve programlara meslek hayatının her aşamasında yer vermek durumundadırlar.

Diğer taraftan gerek örgütsel, gerekse devlet bazında karar verici ve uygulayıcıların tükenmişlik sendromunun etkilerini ve işten ayrılma niyetlerini azaltacak radikal çözümler üretmeleri gerekmektedir. Covid-19 pandemi sürecinin milat olarak kabul edilip, insanüstü çaba sarf ederek aşırı yoğun ve yıpratıcı çalışma temposu sonucunda işten ayrılma niyetlerinin azaltılmasının sağlanması zorunluluk arz etmektedir. Yapılan önceki çalışmalarla ortaya koyulan, -zaten var olan- tükenmişlik ve işten ayrılma niyetinin bu çalışmalarda yer alan; eğitim programları düzenlemek, psikolojik danışmanlık desteği sağlamak, iş zenginleştirilmesi, moral ve motivasyon artırıcı toplantılar, taltif ve takdir çalışmaları ile duygusal emek davranışı geliştirme çabalarının çok ötesinde sistemli ve sürdürülebilir programlarla, ülke genelinde ve tüm sağlık sektörü çalışanlarını içerecek şekilde stratejiler formüle edilmeli ve uygulanmalıdır. Özellikle kişilik özellikleri başta olmak üzere çok farklı değişkenleri dikkate alarak yapılacak kapsamlı ve boylamsal çalışmalar, sağlık çalışanlarının işe alınması, çağın ihtiyacına göre eğitim ve gelişim sağlanması ve elde tutulması konusunda kilit rol oynayacaktır.

\section{Kaynakça}

Abaan, S. ve Duygulu S.(2004). Hemşirelerin Çalıştıkları Kurumdan Ayrılmalarına Yol Açabilecek Olası Nedenlerin ve Örgüte Bağlllıklarının İncelenmesi, Hacettepe Üniversitesi Hemşirelik Yüksekokulu Dergisi, 11(2), 61-73.

Akpınar, A. T., ve Taş, Y. (2011). Acil Servis Çalışanlarının Tükenmişlik İle İş Doyum Düzeyleri Arasındaki İlişkiyi Belirlemeye Yönelik Bir Araştırma, Türkiye Acil Tıp Dergisi, 11(4), 161-165.

Ardıç, K. ve Polatçı S. (2009). Tükenmişlik Sendromu ve Madalyonun Öbür Yüzü: İşle Bütünleşme, Erciyes Üniversitesi İktisadi ve İdari Bilimler Fakültesi Dergisi, 21-46.

Arpacıoğlu, M., S., Baltacı, Z., Ünübol, B. (2021). COVID-19 Pandemisinde Sağlık Çalışanlarında Tükenmişlik, Covid Korkusu, Depresyon, Mesleki Doyum Düzeyleri Ve İlişkili Faktörler, Çukurova Medical Journal, 46(1):88-100.

Avcl, N. ve Küçükusta, D. (2009). Konaklama İşletmelerinde Örgütsel Öğrenme, Örgütsel Bağlllık ve İşten Ayrılma Eğilimi Arasındaki İlişki, Anatolia: Turizm Araştırmaları Dergisi, 20(1), 33-44. http://www.anatoliajournal.com/atad/depo/dergiler/Cilt20 Sayi1 Yil2009 1305116575.pdf.

Baduroğlu, G. E. (2010). Hakim ve Cumhuriyet Savcılarında Psikosomatik Hastalıklar ve Tükenmişlik Sendromu. İstanbul: İstanbul Üniversitesi, Adli Tip Enstitüsü.

Baron, D. N., and Weste. (2007). The Emotional Costs of Caring Incurred By Men and Women in The British Labour Market. Social Science \& Medicine, 65 (10): 2160 - 2171.

Barutçu, E.ve Serinkan, C. (2008). Günümüzün Önemli Sorunlarından Biri Olarak Tükenmişlik Sendromu ve Denizli'de Yapılan Bir Araştırma, Ege Akademik Bakış Dergisi, 8(2), 541-561.

Budak, G. ve Süregevil, O. (2005). Tükenmişlik ve Tükenmişliği Etkileyen Örgütsel Faktörlerin Analizine İlişkin Akademik Personel Üzerinde Bir Uygulama, D.E.Ü.I.I..B.F. Dergisi, Cilt:20, Sayı:2, 95-108.

Cortese, G.C. (2012). Predictors of Critical Care Nurses Intention To Leave The Unit, The Hospital, And The Nursing Profession. Open Journal of Nursing, 3, 311-326.

Çalışkan, A. ve Bekmezci, M. (2019). Aşırı İş Yükünün İşten Ayrılma Niyetine Etkisinde İş Tatmini ve Yaşam Tatmininin Rolü: Sağlık Kurumu Çalışanları Örneği. Adıyaman Üniversitesi Sosyal Bilimler Enstitüsü Dergisi, 11(31), 381-431.

Çalışkan, A. ve Özkan H. (2020). Örgütsel Bağllı̆̆ın Tükenmişliğe Etkisi İş Tatmininin Aracılık Rolü Mersin İli Kamu Hastaneleri Hemşirelerine Yönelik Bir Uygulama, Afyon Kocatepe Üniversitesi Sosyal Bilimler Dergisi, 22(1):1 80-194. 
Çalışkan, A. ve Pekkan, N.U. (2019). Sağlık Sektörü Çalışanlarında Tükenmişlik Duygusunun İşten Ayrılma Niyetine Etkisi: Kişi-Örgüt Uyumunun Aracılık Rolü, Business and Economics Research Journal, 10 (2), 469-481.

Çarıkçı, İ. H., ve Çelikkol, Ö. (2009). İş-Aile Çatışmasının Örgütsel Bağlılık Ve İşten Ayrılma Niyetine Etkisi, Süleyman Demirel Üniversitesi Sosyal Bilimler Enstitüsü Dergisi, (9), 153-170.

Çetin Aydın, G., Aytac, S. ve Sanlı, Y. (2021). İşe İlişkin Duygular, İş Stresi ve Tükenmişliğin İşten Ayrılma Niyeti Üzerindeki Etkisi: Hemşireler Üzerinde Bir Araştırma. Journal of Social Policy Conferences. https://doi.org/10.26650/jspc.2021.80.0011.

Çetin, F., Basım, H.N. ve Aydoğan, O. (2011). Örgütsel Bağl1lı̆̆ın Tükenmişlik İle İlişkisi: Öğretmenler Üzerine Bir Araştırma. Selçuk Üniversitesi Sosyal Bilimler Enstitüsü Dergisi. 25, 61-70,

Dede, M., Çınar, S. (2008). Dahiliye Yoğun Bakım Hemşirelerinin Karşılaştıkları Güçlükler ve İş Doyumlarının Belirlenmesi, Maltepe Üniversitesi Hemşirelik Bilim ve Sanatı Dergisi, 1(1), 3-14.

Demir A. (1999). Hemşirelerin Tükenmişlik Düzeyleri ve Tükenmişliği Etkileyen Bazı Faktörlerin İncelenmesi, Hacettepe Üniversitesi Hemşirelik Yüksek Okulu Dergisi, 6 (1-2).

Demir, A., Ulusoy, M., Ulusoy, M. F. (2003). Investigation of factors İnfluencing Burnout Levels in the Professional And Private Lives Of Nurses. Int J Nurs Stud, 40, 807-827.

Dolgun, U. (2012). Tükenmişlik Sendromu, (Ed.Derya Ergun Özler), Örgütsel Davranışta Güncel Konular, Bursa, Ekin Basım Yayın Dağıtım, 287-312,

Dolunay, A. B. ve Piyal, B. (2003). Öğretmenlerde Bazı Mesleki Özellikler Ve Tükenmişlik. Kriz Dergisi, 11(1), $35-48$.

Duquette A., Kerouac S., Sandhu, B. (1994). Factors Related to Nursing Burnout: A Review of Empirical Knowledge, Issues Mental Health Nursing 15(4): 337-358.

Ebrinç, S., Açıkel, C., Başoğlu, C., Çetin, M., Çeliköz, B. (2002). Yanık Merkezi Hemşirelerinde Anksiyete, Depresyon, İş Doyumu, Tükenme ve Stresle Başa Çıkma: Karşılaştırmalı bir Çalışma, Anadolu Psikiyatri Dergisi, 3, 162-168.

Embriaco, N., Papazian, L., Kentish-Barnes, N., Pochard, F., Azoulay, E. (2007). Burnout Syndrome Among Critical Care Healthcare Workers. Current Opinion in Critical Care, 13, 482- 488.

Ergin C. (1992). Doktor ve Hemşirelerde Tükenmişlik ve Maslach Tükenmişlik Ölçeğinin Uyarlanması, Türk Psikologlar Derneği Yayınları, Ankara, 143-154.

Falgueras, M. V., Muñoz, C. C., Pernas, F. O., Sureda, J. C., López, M. P. G., and Miralles, J. D. (2015). Burnout Y Trabajo En Equipo En Los Profesionales De Atención Primaria. Atención Primaria, 47(1), 25-31.

Flinkman, M., Laine, M., Leino-Kilpi, H., Hasselhorn, H.M,, Salantere, S. (2008). Explaining Young Registered Finnish Nurses' İntention To Leave The Profession: A Questionnaire Survey. International Journal of Nursing Studies, 245, 727-739.

Freudenberger, H.J. (1974). Staff Burn-Out, Journal of Social Issues, Vol.30, Number 1, 159-165.

Gardulf A., Söderström I., Orton M., Eriksson L. E., Arnetz B. \& Nordström G. (2005). Why do Nurses at a University Hospital Want to Quit Their Jobs?, Journal of Nursing Management, 13, 329-337.

Gieter, D.S., Hofmans, J., Pepermans, R. (2011). Revisiting the impact Of Job Satisfaction And Organizational Commitment On Nurse Turnover İntention: An İndividual Differences Analysis, International Journal of Nursing Studies, 48, 1562-1569.

Hayes, L.J., O’Brien Pallas, L., Duffield, C., Shamian, J., Buchan, J., Hughes, F., et al. (2012). Nurse Turnover: A Literature Review - An Update, International Journal of Nursing Studies, 49:7, 887-905.

Heinen M.M., van Achterberg T., Schwendimann R. et al. (2013) Nurses' İntention To Leave Their Profession: A Cross Sectional Observational Study İn 10 European Countries, International Journal of Nursing Studies $50(2), 174-184$. 
Ö. Köroğlu - E. Bahar 13/4 (2021) 3453-3466

Kaçmaz, N. (2005). Hemşirelerde İş Stresi ve Tükenmişlik, İ.Ü.F.N. Hem Dergisi, 13(54), 65-75.

Karadağ F, Karagöz N, Ateşçi Ç.A, Varma G, Oğuzhanoğlu N.K. (2001). Denizli İli'nde Çalışan Hemşirelerde İş Doyumu, Nöropsikiyatri Arşivi, 38(4).

Karadağ, G., Sertbaş, G., Güner, İ. C., Taşdemir, H. S., Özdemir, N. (2002). Hemşirelerin İş Doyumu Ve Tükenmişlik Düzeyleri İle Bunları Etkileyen Bazı Değişkenlerin İncelenmesi. Hemşirelik Forumu Dergisi, 5(6), 8-15.

Karwowski, W., Jang, R.L., Rodrick, D., Peter, M.Q. (2005). Self-Evaluation of Biomechanical Task Demons, Work Environment and Perceived Risk of Injury by Nurses: A Field Study, Occupational Ergonomics, 5: 13-27.

Kebapçı, A. ve Akyolcu, N. (2011). Acil Birimlerde Çalışan Hemşirelerde Çalışma Ortamının Tükenmişlik Düzeylerine Etkisi, Türkiye Acil Tip Dergisi, 11(2), 59-67.

Kemeröz Karakaya, H. (2017). Psikiyatri Kliniğinde Çalışan Hemşirelerde İş Doyumu, Tükenmişlik Düzeyi Ve İlişkili Değişkenlerin İncelenmesi, Yüksek Lisans Tezi. Okan Üniversitesi, Sağlık Bilimleri Enstitüsü, İstanbul. https://tez.yok.gov.tr/ (Tez No. 466282).

Kılıç., T, ve Seymen., O.A. (2011). Sağlık Sektöründe, Tükenmişlik Sendromuna Etki Eden Faktörlerin Analizi ve Bir Araştırma, Yönetim ve Ekonomi Araştırmaları Dergisi, Sayı, 16, 47-67.

Kocabıyık, Z. O., Çakıcı, E. (2008). Sağlık Çalışanlarında Tükenmişlik ve İş Doyumu, Anadolu Psikiyatri Dergisi, 9, 132-138.

Kristensen, T.S., Borritz, M., Villadsen, E. and Christensen, K.B. (2005). The Copenhagen Burnout Inventory: A New Tool for the Assessment of Burnout, Work \& Stress. 19(3), 192- 207

Lavoie, T.M., Paquet, M., Marchionni, C., Drevniok, U. (2011). Turnover Intention Among New Nurses, Journal of Nursing in Staft Development, 27:1, 39-45.

Lee H., Song R., Suk Y. (2003). A Comprehensive Model for Predicting Burnout in Korean Nurses, Journal of Advanced Nursing 44(5): 534-545.

Maslach, C. \& Jackson, S. E. (1981). The Measurement Of Experienced Burnout, Journal of Occupational Behavior, Vol.2, 99-113.

Maslach, C., Schaefeli, W. B. and Leiter, M. (2001). Job Burnout, Annual Review of Psychology, 52(1), 397422.

McCarthy, G., Tyrrell, M.P., Lehane, E. (2007). Intent To “Leave" Or "Stay" İn Nursing. Journal of Nursing Management, 15; 248-255.

Metin., Ö, ve Özer., F,G, (2007). Hemşirelerin Tükenmişlik Düzeylerinin Belirlenmesi, Atatürk Üniversitesi Hemşirelik Yüksekokulu Dergisi, Cilt, 10, Sayı, 1, 58-66.

Meydan, C. H., Basım, H. N., ve Çetin, F. (2011). Örgütsel Adalet Algısı ve Örgütsel Bağlılığın Tükenmişlik Üzerine Etkisi:Türk Kamu Sektöründe Bir Araştırma, Bilig(57), 175-200.

Onay, M. ve Kılcı S. (2011). 'İş Stresi Ve Tükenmişlik Duygusunun İşten Ayrılma Niyeti Üzerine Etkileri: Garsonlar ve Aşçıbaşılar, Organizasyon ve Yönetim Bilimleri Dergisi, 3(2), 363-372.

Özbaş, A., Solmaz, Ş., Çavdar, İ., Bolol, N., Akyolcu, N., Urhan, S., Yıldız, L. (2006). Kulak Burun Boğaz Kliniğinde Çalışan Hemşirelerde Tükenmişlik, İstanbul Üniversitesi Florence Nightingale Hemşirelik Yüksekokulu Dergisi, 14(56), 41-48.

Pathman, D. E., Konrad, T. R., Williams, E. S., Scheckler, W. E., Linzer, M., \& Douglas, J. (2002). Physician Job Satisfaction, Job Dissatisfaction, And Physician Turnover. Journal of Family Practice, 51(7), 593.

Polat, M., ve Meydan, C. H. (2010). Örgütsel Özdeşleşmenin Sinizm ve İşten Ayrılma Niyeti İle İlişkisi Üzerine Bir Araştırma, Savunma Bilimleri Dergisi, 9(1), 145-172. 
Ö. Köroğlu - E. Bahar 13/4 (2021) 3453-3466

Poncet, M. C., Toullic, P., Papazian, L., Kentish-Barnes, N., Timsit, J., Pochard, F., Chevret, S., Schlemmer, B., Azoulay, E. (2007). Burnout Syndrome in Critical Care Nursing Staff, American Journal of Respiratory and Critical Care Medicine, 175, 699-703.

Ribeiro Vf, Filho Cf, Valenti Ve, Ferreira M, De Abreu Lc, De Carvalho Td, Et Al. (2014). Prevalence Of Burnout Syndrome in Clinical Nurses At A Hospital Of Excellence, Int Arch Med.7:22.

Rosin, H. M., and Korabik, K. (1991). Workplace Variables, Afective Responses, And İntention To Leave Among Women Managers, Journal Of Occupational Psychology, 64(4), 317-330.

Rusbelt, C. E., Farrell, D., Rogers, G. \& Arch G. Mainous, III., (1988). Impact of Variables On Exit, Voice, Loyalty And Neglect: An İntegrative Model Of Responses To Declining Job Satisfaction, Academy Of Management Journal, 31, 599-627.

Salmela-Aro, K., Tolvanen, A. and Nurm1, J.E. (2009). Achievement Strategies During University Studies Predict Early Career Burnout and Engagement, Journal of Vocational Behavior. 75, 162- 172.

Savran, S. (2013), Üçüncü Büyük Depresyon Kapitalizmin Alacakaranlı̆̆ (Vol. 198). Yordam Kitap.

Sayıl I., Haran S., Ölmez Ş., Özgüven H. D. (1997). Ankara Üniv. Hastanelerinde Çalışan Doktor ve Hemşirelerin Tükenmişlik Düzeyleri, Kriz Dergisi, (2): 71-77.

Shimızutanı, M., Odagırı, Y., Ohya, Y., Shımomitsu, T., Krıstensen, T.S., Maruta, T., Iımorı, M. (2008). Relationship of Nurse Burnout with Personality Characteristics and Coping Behaviors, Industrial Health, $46,326-335$.

Silah, M. (2005). Endüstride Çalışma Psikoljisi, Ankara: Seçkin Yayıncılık.

Simat, Ö. (2007). Psikiyatri Kliniklerinde Çalışan Hemşirelerin Tükenmişlik Düzeylerinin Araştırılması, Yüksek Lisans Tezi, İstanbul Üniversitesi, Sağlık Bilimleri Enstitüsü, İstanbul.

Skaalvık, E.M. and Skaalvık, S. (2009). Does School Context Matter? Relations With Teacher Burnout and Job Satisfaction, Teaching and Teacher Education. 25, 518-524.

Skeja, A. (2012). Çalışanların Tükenmişlik Düzeyi İle İş Tatmini Arasındaki İlişki ve Bir Araştırma. İstanbul: İstanbul Üniversitesi, Sosyal Bilimler Enstitüsü.

Sürer, P., Kocaman, G. (2009). Hastanede Çalışan Hemşirelerin İşten Ayrılma Nedenleri. DEÜ Hemşirelik Yüksekokulu Yaz Konferans1- 6, İzmir.

Sürgevil Dalkılıç, O. (2014). Çalışma Hayatında Tükenmişlik Sendromu, Nobel Yayınları.

Şahin, D., Turan, F. N., Alparslan, N., Şahin, İ., Faikoğlu, R., Görgülü, A. (2008). Devlet Hastanesinde Çalışan Sağlık Personelinin Tükenmişlik Düzeyleri, Nöropsikiyatri Arşivi, 45, 116-121.

Şen Bezirci, S., Kocaman, G. (2013). Farklı Kuşaklardaki Hemşirelerin Meslekten ve İşten Ayrılma Niyetleri İle İş Doyumlarının İncelenmesi. 1. Ulusal Hemşirelikte Yönetim Sempozyumu, İstanbul.

Şıklar, E. ve Tunalı, D. (2012). Çalışanların Tükenmişlik Düzeylerinin İncelenmesi: Eskişehir Örneği, Dumlupınar Üniversitesi Sosyal Bilimler Dergisi, 33, ss. 75-84

Takase, M. (2010). A Concept Analysis Of Turnover İntention: Implications For Nursing Management. Collegian, 17, 3-12.

Taycan O, Kutlu L, Çimen S, Aydın N. (2006). “Bir Üniversite Hastanesinde Çalışan Hemşirelerde Depresyon ve Tükenmişlik Düzeyinin Sosyodemografik Özelliklerle İlişkisi". Anatolian Journal of Psychiatry. 7:100-108.

Tayfun, A., ve Çatır, O. (2014). Hemşirelerin Örgütsel Sinizm Düzeylerinin İncelenmesi, İşletme Araştırmaları Dergisi, 6(3), 346-365.

Tekin, İ.Ç. (2021). Sağlık Kurumları Çalışanlarında Tükenmişlik, Editörler Urgan, S., Erdoğan, P., Sağllk Perspektifinden Örgütsel Psikoloji, Eğitim Yayınevi, İstanbul, 35-52. 
Ö. Köroğlu - E. Bahar 13/4 (2021) 3453-3466

Tett, R. P., and Meyer, J. P. (1993). Job Satisfaction, Organizational Commitment, Turnover İntention, And Turnover: Path Analysis Based On Meta-Analytic Findings, Personnel Psychology, 46, 259-293.

Yakut, E., Kuru, Ö. ve Güngör, Y. (2020). Sağlık Personelinin Covid-19 Korkusu İle Tükenmişliği Arasındaki İlişkide Aşırı İş Yükü Ve Algılanan Sosyal Desteğin Etkisinin Yapısal Eşitlik Modeliyle Belirlenmesi, Ekev Akademi Dergisi, 83: 241-262.

Yavuzyılmaz, A., Topbaş, M., Çan, E., Çan, G., Özgün, Ş. (2007). Trabzon İl Merkezindeki Sağlık Ocakları Çalışanlarında Tükenmişlik Sendromu İle İş Doyumu Düzeyleri Ve İlişkili Faktörler, TSK Koruyucu Hekimlik Bülteni, 6 (1), 41-50.

Yazıcıŏ̆lu, Y. ve Erdoğan, S. (2014). SPSS Uygulamalı Bilimsel Araştırma Yöntemleri. Ankara: Detay Yayıncılık. 